\title{
Features of Regulatory Control and Accounting of Labor Remuneration in Budgetary Healthcare Institutions (Through the Example of Omsk Region)
}

\author{
Golova E.E.* \\ Department of Economics, Accounting and Financial \\ Control \\ Omsk State Agrarian University named after P.A. Stolypin \\ Omsk, Russia \\ ee.golova@omgau.org
}

\author{
Baranova I.V. \\ Department of Economics, Accounting and Financial \\ Control \\ Omsk State Agrarian University named after P.A. Stolypin \\ Omsk, Russia \\ iv.baranova@omgau.org
}

\author{
Balandaeva Yu.G. \\ Division of financing of education, science and culture \\ Department of Social and Cultural Policy \\ Ministry of Finance of Omsk Region \\ Omsk, Russia \\ yug.balandaeva17z37@omgau.org
}

\begin{abstract}
Nowadays the issues of labor costs are the most relevant in Russia. In the context of the spread of coronavirus infection, this issue became even more significant in healthcare. Even before the pandemic, our country was actively improving the legal framework in the field of healthcare as the basis for the formation of a competent system for the remuneration of medical workers. At the federal level, the decisions are being made to increase the level of wages of medical workers, as well as to determine the optimal structure of the wage fund. In addition, the underdevelopment of the regulatory system in the field of health is revealed. In these conditions, accounting serves as the main provider of information and a source for the analysis of the transformations taking place in medical institutions regarding wages. The authors examined the stages of development of legislation on the remuneration of medical workers and substantiated the need to clarify such concepts as analytical and synthetic accounting in order to calculate remuneration. In addition, the article discusses the features of wage accounting and its documenting in the healthcare system as one of the varieties of budget accounting.
\end{abstract}

Keywords - budget accounting, regulation in budget, remuneration, synthetic and analytical accounting.

\section{INTRODUCTION}

Nowadays the issue of financial security of health care staff is particularly relevant because of the uncompetitive level of wages in this branch, and therefore, the decisions are being made to increase the average wage of medical workers at the level of the President of the Russian Federation. The Russian Government sets recommendations on the optimal structure of the medical wage fund of employees, part-time workers, etc.
In the conditions of insufficient budgetary funds for the realization of the tasks, healthcare institutions need to find reserves. Due to this reason, for the purpose of timely selection of managerial decisions, the role of economic analysis of the efficiency of labor resources and wage fund in healthcare institutions and accounting as a source of information for analysis is growing. The results of the analysis serve as the basis for the development of measures to mobilize the identified reserves. It is necessary to note that at present there is a clear insufficiency of the existing regulatory and methodological base necessary for a full economic analysis of this direction. It is all these aspects that determine the relevance and significance of the research topic.

Practical and theoretical aspects of accounting for wage calculations in budgetary institutions were covered in the works of such national scientists as Danilova V.V., Bespalova M.V., Zabolonkova O., Sharapova N.A., Kozmenkova S.V., Zaripova M., Orlova E.V., Manichkina M.V., Kupina V.V., Sidavskaya V.V., Zhuklinets I.I. et al.

The features of remuneration in budgetary institutions were considered in the works of such authors as Filatov V.N., Kadyrov F.N., Yugay M.T., Sokolova A.V., Sharapova V.M. and etc.

The problems of the methods of conducting an economic analysis of the efficiency of labor costs in budgetary institutions, including healthcare institutions, were studied by the following authors: Zarubina O.A., Dashkova E.S., Yashina N.I., Emelyanova O.V., Goleva O.P., Yashina N.G., Grishunina I.A., Yashin K.S., Kudelina O.V., Tulupova O.N. and etc. 
The object of the study is the financial and economic activity of this institution in terms of labor costs, the results of which are reflected in the accounting system of the institution and are subjected to economic analysis.

The scientific novelty of the study is in the author's interpretation of the definition, which has no theoretical analogues in the scientific community, "synthetic and analytical accounting of wage calculations", characterizing these two types of accounting from the point of view of practical application for budgetary institutions.

The theoretical significance of the study is in the improvement of the individual stages of accounting organization for wage calculations in budgetary healthcare institutions.

Despite the available scientific developments in this area, there is a problem related to the insufficient development of the methodological foundations and practical provisions for the organization of accounting in healthcare institutions.

However, it is necessary to note that public health services have some economic features in comparison with other types of services. One of them is that all state institutions, including healthcare institutions, are divided into the following types: state, budget, and autonomous [1].

This division occurred at one of the stages of the reformation of the budget sector of the Russian economy through the adoption of Federal Law No. 83-FL "On Amending Certain Legislative Acts of the Russian Federation in Connection with the Improvement of the Legal Status of State (Municipal) Institutions" on May 8, 2010. As a result, the restriction on type of health care institutions was established, the main idea of which was that the state institutions of the constituent entities of the Russian Federation, the source of financial support of which were means of compulsory medical insurance, cannot be created in the form of state-owned institutions (Article 31) [2].

In relation to Omsk region, it was established that at the end of 2018, 110 state institutions in the field of health care were functioning [3], 15 institutions of which were not involved in the implementation of territorial compulsory health insurance programs [4]. Thus, we conclude that most of the public health institutions of Omsk Region are budgetary institutions, which in turn are part of the state modern economic system, where the market and the state constantly interact when solving socially significant issues.

\section{MATERIALS AND METHODS}

During the course of the research, we found that at the legislative level there is no direct definition of such a thing as "wage fund". Therefore, under the wage fund (hereinafter referred to as WF), this work considers the expenses of public organizations, including health care and labor compensation for a certain period of time.

Another feature of the public sector in healthcare is the combination of measures for state interaction with the contract system, which is presented in two forms: collectivecontractual and individually-contractual. However, since the object of our research in this article is health care institutions, it is necessary to note that the most common is the time-rate and bonus form of remuneration, the essence of which is the payment of bonuses, which are determined as a percentage of wage in case of performance of any qualitative and quantitative indicators.

The Decree of Omsk Region Administration of October 15, 2008 No. 172-p “On industry-specific wage systems for employees of public, autonomous and state-owned institutions in Omsk region" [5] since 2009 launched the transition of a new wage system for employees the healthcare system and the entire public sector. This was a kind of initial stage of wage reform in Omsk region as a whole. In 2012, the main changes in the remuneration of health workers were outlined, among which the main guideline was the increase in wages.

In 2012, the Decree of the President of the Russian Federation of May 7, 2012 No. 597 "On measures to implement the state social policy" was issued, which marked the beginning of the second stage for social sphere, including health care and labor remuneration. The Program for the phased improvement of wage system in state (municipal) institutions for 2012-2018 was approved [6], the purpose of which was to stimulate the improvement of the quality of services in social sphere due to the effective work of its employees, which implied the dependence of wages on the amount of free medical services provided to population.

The developed and approved effective contract was the basis for the assessment of the work of medical staff. In fact this contract represented a form of an employment contract and description of the specific duties of medical staff, working conditions, criteria for the evaluating of effectiveness, which served as the basis for assigning incentive payments, the amount of which depended on the quality of service delivery and labor results [7]

In addition, the fact that the wage fund is formed from mandatory medical insurance funds, funds allocated from the regional budget of Omsk region, as well as extra-budgetary funds is among the features of budgetary accounting in the field of healthcare. In the context of the transition to compulsory medical insurance, the wage fund, which is monthly subject to distribution, is the result of earning funds by a medical institution on "money follows a patient" principle.

However, the fact is that not all money earned in this way is allocated specifically to the wage fund for medical staff. The money from this fund is also allocated for the purchase of medicines, payment for utility services, etc. In this case it is possible to obtain the information on all amounts using the system of imposed accounting in an institution. It is accounting that serves as a link between the mechanisms of the reformation of healthcare sector and a medical institution.

The wage fund, determined for the employees according to budgetary financing, is formed on the basis of the approved schedule. At the same time, the wage fund for compulsory medical insurance and paid medical services is the combination of funds for the payment of wages to employees of an institution, formed according to the standard on income and the method of payment for medical care, annually 
approved in state guarantee programs of free medical care as part of the basic compulsory medical insurance.

At the same time, the actual wage fund, the so-called wage fund, determined for medical workers in occupied positions in accordance with tariff classification, is not equal to the wage fund, determined in proportion to the tariff structure, and it is only its constituent part [8]. Thus, the Wage Fund includes a wage fund and a material incentive fund, the source of which is the difference between the Wage Fund and salary fund.

It is also necessary to note that in 2019 the third stage of the reformation of wage system in healthcare was outlined. The President of the Russian Federation approved the list of Guidelines as a result of the meeting on the modernization of primary health care, held on August 20, 2019. One of which was the order of the Government of the Russian Federation to analyze the level of salaries of medical workers of medical facilities providing primary health care and the effectiveness of the existing labor payment systems.

Thus, normative regulation is the initial stage in labor remuneration accounting. It includes the procedures and methods of accounting that each institution develops, it includes the amounts of wages and leave allowances of medical workers, as well as all types of retentions and the amount of contributions to extra-budgetary funds may also be included.

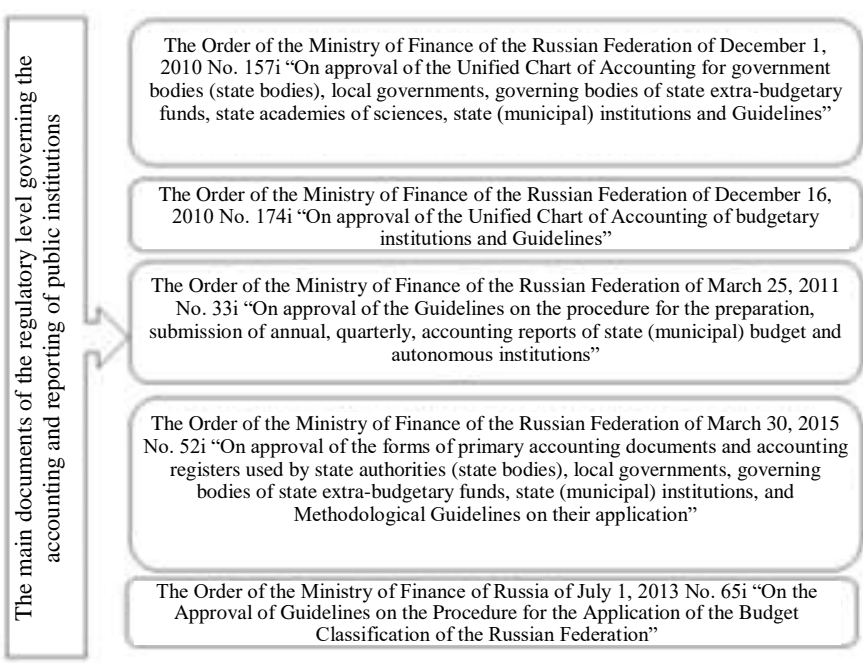

Fig. 1. Primary labor payment documentation

\section{DISCUSSION}

One of the main regulatory documents in the field of accounting, including budget, is the Federal Law of December 6, 2011 402-FL "On Accounting" [9], since it contains the basic norms and requirements, and obliges all economic entities to keep records, which makes it possible to obtain reliable and complete information.

According to the Law on Accounting, one of the requirements is to reflect the facts of economic activity in the primary documentation, but in addition to documenting, the fundamental elements of budgetary accounting can also be called: a working chart of accounts, forms of accounting and reporting in an institution. These terms are also related to the field studied in this article - the field for accounting of labor payment.

The documentation in budgetary accounting has its own peculiarities and is regulated by Order of the Ministry of Finance of Russia of March 30, 2015 No. 52n "On approval of the forms of primary accounting documents and accounting registers used by state authorities (state bodies), local governments, governing bodies of state extra-budgetary funds, state (municipal) institutions, and the Guidelines for their application" [10]. The main documents related to the category of primary are shown in Figure 1, and the procedure for filling them out is prescribed in the aforementioned Order.

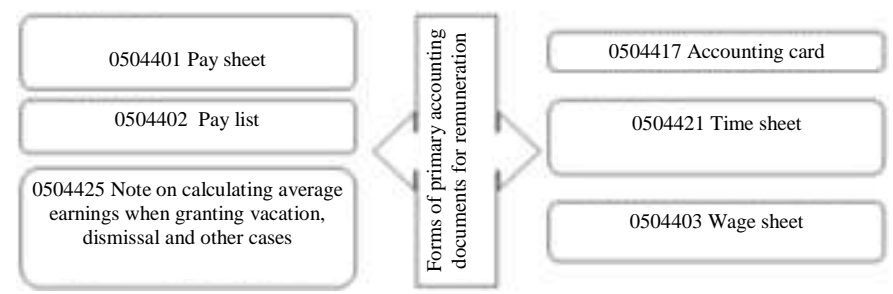

Fig. 2. Accounting regulation in budgetary healthcare institutions

One of the features of budgetary accounting, which distinguishes it from others, is that this type of accounting is carried out by sources of financing. Nevertheless, the normative regulation of the issues of remuneration calculation of labor in budgetary institutions, including health care, has certain features, which is reflected in the legislation (Fig. 2).

It is necessary to note that Law 402-FL does not provide definitions for synthetic and analytical accounting [11], but the meaning and purpose of these definitions still remains. Therefore, some economists proposed their definitions of these concepts (table 1).

TABLE I. ANALYSIS OF THE INTERPRETATION OF DEFINITIONS OF SYNTHETIC AND ANALYTICAL ACCOUNTING

\begin{tabular}{|c|c|c|c|}
\hline \multirow[t]{2}{*}{ No. } & \multirow{2}{*}{$\begin{array}{c}\text { Name of } \\
\text { researcher }\end{array}$} & \multicolumn{2}{|c|}{ Interpretation of the author } \\
\hline & & Synthetic ccounting is & Analytical accounting is \\
\hline 1 & $\begin{array}{l}\text { M. } \\
\text { Kosulnikova }\end{array}$ & $\begin{array}{l}\text { generalized accounting } \\
\text { carried out on synthetic } \\
\text { accounts and in accounting } \\
\text { registers of property, } \\
\text { liabilities and business } \\
\text { transactions }\end{array}$ & $\begin{array}{l}\text { accounting, which is } \\
\text { maintained on analytical } \\
\text { accounts (sub-accounts) } \\
\text { and in accounting registers } \\
\text { in the context of certain } \\
\text { types of property, liabilities } \\
\text { and business transactions, } \\
\text { as well as supplements } \\
\text { synthetic accounting data }\end{array}$ \\
\hline 2 & $\begin{array}{l}\text { A. } \\
\text { Anischenko }\end{array}$ & $\begin{array}{l}\text { accounting of generalized } \\
\text { accounting data on the types } \\
\text { of property, liabilities and } \\
\text { business transactions for } \\
\text { certain economic } \\
\text { characteristics, which is } \\
\text { maintained on synthetic } \\
\text { accounting accounts }\end{array}$ & $\begin{array}{l}\text { detailed information on } \\
\text { property, liabilities and } \\
\text { business transactions within } \\
\text { each synthetic account }\end{array}$ \\
\hline 3 & $\begin{array}{l}\text { N. } \\
\text { Evdokimova }\end{array}$ & $\begin{array}{l}\text { accounting for generalized } \\
\text { or aggregate indicators on } \\
\text { the types of property, assets, } \\
\text { liabilities, as well as on } \\
\text { business transactions } \\
\text { grouped by certain } \\
\text { economic characteristics }\end{array}$ & $\begin{array}{l}\text { a detailed type of } \\
\text { accounting, which } \\
\text { contains more detailed } \\
\text { information about } \\
\text { individual business } \\
\text { transactions and other } \\
\text { accounting indicators in } \\
\text { the context of analytical } \\
\text { accounts }\end{array}$ \\
\hline
\end{tabular}


In relation to the study of accounting, these concepts do not disclose the details of accounting, and wordings that reveal the concepts of synthetic and analytical accounting of calculations in the scientific literature by economists are not proposed. It is not revealed what kinds of expenses are grouped during synthetic accounting and what needs to be detailed in the calculations in analytical accounting.

The transactions with funds of budgetary institutions are accounted by the codes of the Classification of Transactions of the General Government Sector (CTGGU), used for the purpose of grouping transactions carried out in the general government sector, depending on their economic content. This code, the normative regulation of which is determined by the Budget Code, is an element of the budget classification, the specifics of the use of these codes is reflected in the regulatory documents of the Ministry of Finance of the Russian Federation regarding regulation of accounting budget accounting. Thus, in order to reflect information on wages and their accrual, CTGGU 210 codes are formed, and they are also divided internally into a number of accounts: 211 - Wages; 212 - Other payments; 213 Assumptions on payment of wages [12].

The set of CTGGU codes form a budget accounting, the structure of which consists of 26 categories. It is a distinctive feature of the structure of the budgetary accounting (Fig. 3).

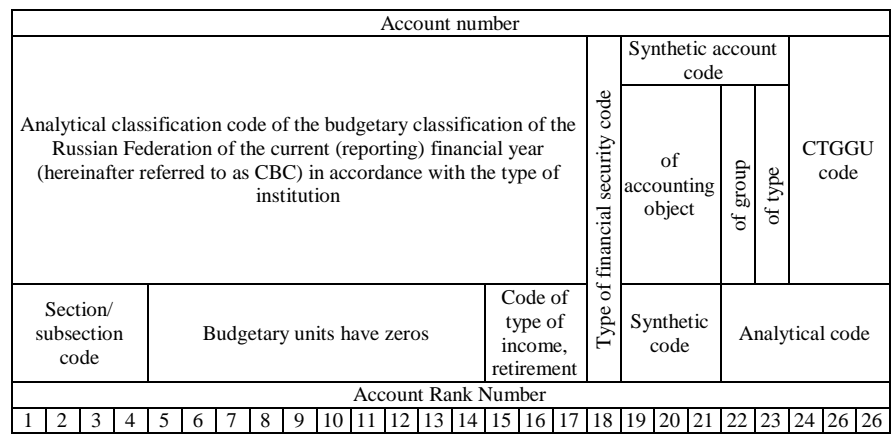

Fig. 3. Account structure in budgetary accounting

According to the Order No. 174n, the purpose of the analytical accounts reflects the information:

- Ranks 1-4 r reflect the code of the institution's function, in the case of healthcare facilities it can be, for example, 0901 - Hospital care;

- Ranks 5-14 - usually zeros are put here;

- Ranks 15-17 represent an analytical code of income / expenses, for example, in terms of wages, it will reflect: 111 - Institutional remuneration fund or 119Compulsory social insurance contributions for employee remuneration and other payments to employees of institutions;

- Rank 18th - this is the encoding of financing, for example, the number 2 means income from any activity, 5 - subsidies for other purposes, etc.;

- Ranks 19-23 describe the encoding of the synthetic account, accounting group;
- Ranks 24-26 - this is the coding of CTGGU for the purpose of economic maintenance [13].

\section{RESULTS}

According to the above mentioned aspects, it follows that synthetic accounting is a summary of information on synthetic accounts already approved in relation to the accounting data on the types of property, liabilities and business transactions for certain economic characteristics.

Analytical accounting is a detailed accounting of accounts developed by the institution independently and included in the operating chart of accounts in the prescribed manner, disclosing information on synthetic accounts in order to generate operative reporting necessary for internal and external users.

If we consider the construction of accounts from the position of remuneration, we must say that these calculations are reflected in the synthetic accounts: 030211 - "wages"; $\begin{array}{lllllll}0 & 302 & 12 & \text { "Other payment accountings"; } 0 & 302 & 13 & -\end{array}$ "Calculations of payments for labor remuneration" [14].

Accounting and re-accounting of wage amounts in budgetary institutions is reflected in the following codes of synthetic accounts:

030211 - "Wage payment" and 30212 "Other payments" in conjunction with CTGGU code 211 and 212, respectively;

030213 - "Calculation of labor remuneration" should be reflected by the expenses in conjunction with CTGGU 213 the amount accounted for temporary disability benefit, childcare benefit [15].

The regulatory documents governing the accounting and reporting of budgetary institutions do not contain a list of synthetic accounting registers for wage calculations.

Thus, according to Order No. 157n, the data on balance accounts are displayed in balance account, i.e. in the Unified Chart of Accounts. Thus, the synthetic accounting of wage calculations allows accumulating information about the total amounts of calculated and paid wages in an institution, retention of wages, as well as the amounts of calculations to extra-budgetary funds according to the sources of financial and economic activity of a budget institution.

It is necessary to note that the possibility of analytical activity is provided for $5-14$ ranks of a 26-digit account, however, this order has not established indicators in the context of which analytical accounting of these calculations should be carried out [16]. Consequently, an institution has the right to determine these indicators independently, based on the priorities in the disclosure of information. For example, taking into account the need for monthly monitoring of the average wage level of certain categories of medical staff, it is advisable to organize analytical accounting in such a way as to obtain information on groups of personnel or types of calculations directly from the Journal of Transactions [17]. The justification of the author's interpretation of the concepts of synthetic and analytical accounting is presented in Figure 4. 


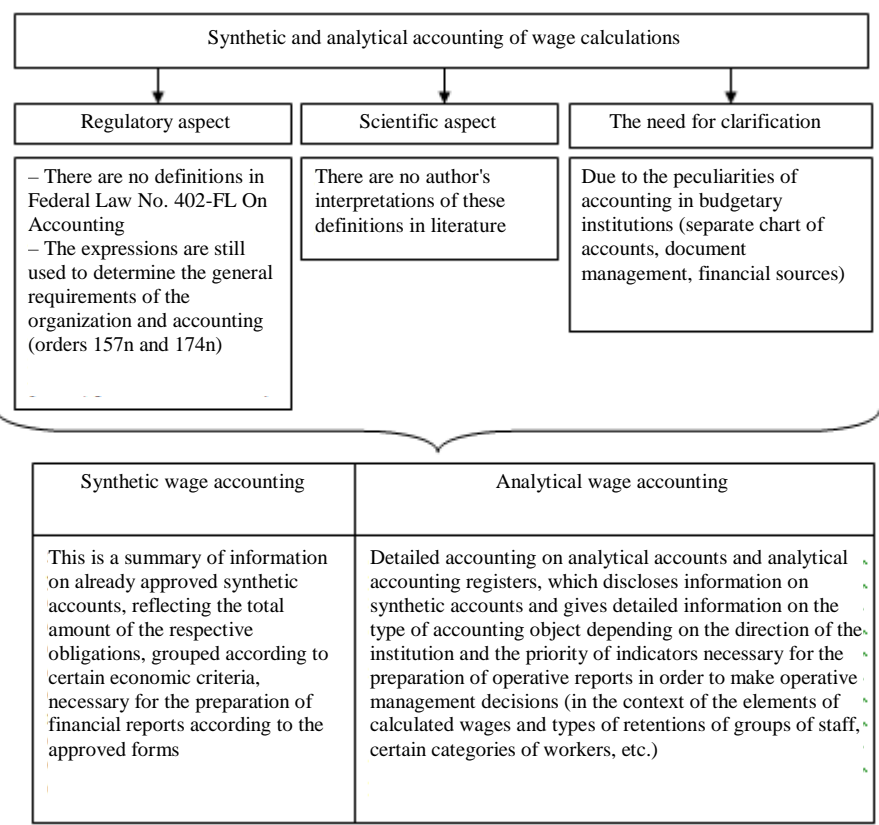

Fig. 4. Author's justification of the concepts of synthetic and analytical accounting

\section{CONCLUSION}

The features of wage accounting calculations, including a current chart of accounts used in a particular institution, forms of primary documents and accounting registers, as well as requirements for the structure of analytical accounting, the procedure for creating reserves for vacation pay, including wage payments (types of reserves, assessment methods of obligations, the date of recognition, etc.) must be fixed in the framework of the accounting policies of a particular institution [18].

The main task of wage accounting is to ensure accurate accounting, time worked and the rate of production, the correct and timely calculation of the amount of wages, retentions, the amount of taxes and insurance contributions [19].

In general, accounting records of wage should provide the collection and grouping of indicators for labor and its payment both for the purpose of preparing up-to-date information on the status of payments for management in order to make necessary managerial decisions, and for preparing financial records [20].

In this case, the grouping of expenses is carried out on the corresponding synthetic accounting necessary for the preparation of financial records, and reflects the total amount of expenses on the corresponding obligations, as well as on the accounts and in the analytical accounting registers, specifying the information on synthetic accounts in the context of elements of wages and types of retentions and by staff groups of certain categories, necessary for operative reports.

\section{References}

[1] E.A. Sargsyants, Remuneration of employees of the public sector: assessment of the situation and the direction of reform (Cand. Dissertation), 2006, 185 p.
[2] M.V. Manichkina, "On the problems of using IPSAS as a tool for reforming accounting and reporting of the public sector", Sci. J. of KubSAU, vol. 129, pp. 1-6, 2017.

[3] V.V. Nazarova, "Evaluation of the effectiveness of the healthcare system in Russia", Populat., vol. 4, chap. 20, pp. 119-134, 2017.

[4] "On the state of public health and the organization of health care in the Omsk Region according to the results of activities for 2018: State Report", Ministry of Health of the Omsk Region, 2019, $132 \mathrm{p}$.

[5] "On the implementation of certain provisions of the Decree of the Government of the Omsk Region of 15 October 2008, no. 172-p (together with the Regulation on the Remuneration of Employees of Budget, Autonomous and Government Institutions of the Omsk Region, in respect of which the functions of the founder are performed by the Ministry of Health of the Omsk Region)", Order of the Ministry of Health of the Omsk Region dated 02.25.2016 no. 11 (as amended on 06/18/2019). Moscow: Information and legal reference system "Consultant Plus", 2019.

[6] "On approval of the Program for the gradual improvement of the wage system in state (municipal) institutions for 2012-2018", Order of the Government of the Russian Federation of 26 November 2012, no. 2190-r. Moscow: Information and legal reference system "Consultant Plus", 2019

[7] V.V. Sidavskaya, "Some Issues of Remuneration in a Budget Health Care Institution", Scientific and Practical Electronic Journal of Science Alley, 2017, vol. 16, pp. 62-65.

[8] O.V. Kudelina, "Evaluation of the effectiveness of the use of resources of the healthcare system of the Tomsk region", Bulletin of Tomsk State University, Economics, 2018, vol. 41, p 109-126.

[9] "On accounting", Feder. Law of December 6, 2011 No. 402-FZ (with the latest revisions and additions of 28 November 2018, no. 344-FZ). Moscow: Information and legal reference system "Consultant Plus", 2019.

[10] On the approval of the forms of primary accounting documents and accounting registers used by state authorities (state bodies), local governments, governing bodies of state extra-budgetary funds, state (municipal) institutions, and guidelines for their application", Order of the Ministry of Finance of Russia dated 30 March 2015, no. 52n (with the latest revisions and additions of 17 November 2017, no. 194n), Moscow: Information and legal reference system "Consultant Plus", 2019.

[11] Modern Economic Dictionary, 6rd ed., Revised. and add., comp. B.A. Reisberg, L.Sh. Lozovsky, E.B. Starodubtseva, Moscow: INFRAM, 2019, $552 \mathrm{p}$.

[12] "On approval of the Chart of Accounts of Budgetary Institutions and the Instructions for its Application", Order of the Ministry of Finance of Russia dated 16.12.2010, no. 174n (with the latest revisions and additions dated 28.12.2018, no. 299n). Moscow: Information and legal reference system "Consultant Plus", 2019.

[13] "On the approval of the Unified Chart of Accounts for government bodies (state bodies), local governments, governing bodies of state extra-budgetary funds, state academies of sciences, state (municipal) institutions and Instructions for its use", Order of the Ministry of Finance of Russia dated 01.12.2010, no. 157n (with the latest revisions and additions dated 28 December 2018, no. 298n). Moscow: Information and legal reference system "Consultant Plus", 2019.

[14] "On the Approval of Instructions on the Application of the Budget Classification of the Russian Federation", Order of the Ministry of Finance of Russia dated 01.07.2013, no. 65n (with the latest amendments and additions dated 20.12.2018 No. 277n). Moscow: Information and legal reference system "Consultant Plus", 2019.

[15] "On approval of the List of types of incentive payments in federal budget, autonomous, state-owned institutions and clarifications on the procedure for establishing incentive payments in these institutions", Order of the Ministry of Health and Social Development of the Russian Federation of 29 December 2007, no. 818 (with the latest revisions. and add. dated September 17, 2010 No. 810n). Moscow: Information and legal reference system "Consultant Plus", 2019.

[16] G.E. Ulumbekova, "Public spending on health care in 2017, or what the industry needs to do in a situation of limited financial resources", Orgzdrav: news, opinions, training, vol. 3-4, pp. 8-17, 2016. 
[17] Uvaleyeva, D. Mukhiyayeva, I. Baranova, M. Valieva, O. Kopylova, "Moving of post-soviet universities in international ratings: case of entrepreneurship education", J. of Entrepreneurship Ed., vol. 22, iss. 6, 2019.

[18] E. Golova, D. Baetova, O. Zaitseva, Y. Novikov, Modernization of the Social Sphere in Terms of the Development of the System of Preschool Education of Child.
[19] V.N. Filatov, "Problems of introducing an effective contract in the field of healthcare: opportunities and risks", Bull. of the North-West State Med. Univer. named after I.I. Mechnikova, vol. 1, pp. 87-97, 2017.

[20] N.G. Yashina, I.A. Grishunina, K.S. Yashin, "Methodology for assessing the effectiveness of managing budgetary resources in the field of healthcare", Econ. anal.: theory and pract., vol. 21, no. 420, pp. 13-26, 2018. 